\title{
Barang Bekas Di Sekitarku (BARBEKU) Sebagai Alat Peraga Sederhana Untuk Meningkatkan Pemahaman Hukum III Newton
}

\author{
Ratna Dewi Masturoh ${ }^{1,{ }^{*}}$, Marmi Sudarmi ${ }^{1,2}$, Diane Noviandini ${ }^{1,2}$ \\ ${ }^{1}$ Program Studi Pendidikan Fisika, Fakultas Sains dan Matematika, Universitas Kristen Satya Wacana, \\ Salatiga, Jawa Tengah 50711 \\ ${ }^{2}$ Pusat Studi Pendidikan Sains, Teknologi dan Matematika (e-SisTem),Fakultas Sains dan Matematika, \\ Universitas Kristen Satya Wacana
}

*email korespondensi: $\underline{\text { ratnadewi230@gmail.com }}$

\begin{abstract}
ABSTRAK
Penggunaan alat peraga dalam proses pembelajaran dapat membantu guru dalam memperjelas penyajian dan penyampaian informasi kepada peserta didik, sehingga peserta didik lebih mudah memahami informasi tersebut. Namun pada kenyataanya tidak semua sekolah memiliki alat peraga sebagai media pembelajaran karena keterbatasan alat yang dimiliki, terutama di daerah-daerah terpencil. Tujuan penelitian ini adalah untuk mengembangkan alat peraga sederhana pada materi Hukum III Newton dengan memanfaatkan barang-barang bekas yang ada di sekitar kita menjadi media pembelajaran, serta mengimplementasikan media pembelajaran BARBEKU yang dibuat sebagai pembelajaran di kelas dan membantu siswa meningkatkan pemahaman tentang materi hukum III Newton. Penelitian ini menggunakan metode penelitian tindakan kelas (PTK) dengan tipe guru sebagai peneliti. Instrumen penelitian untuk pengumpulan data yang digunakan yaitu RPP, Lembar Observasi, Lembar Kuesioner dan soal evaluasi siswa. Responden penelitian 24 siswa kelas 8 SMP Negeri 3 Tuntang. Berdasarkan tabel rekapitulasi lembar observasi diperoleh persentase keberhasilan $79,17 \%$, dari tabel rekapitulasi lembar kuesioner diperoleh respon positif siswa menyatakan bahwa alat peraga sederhana yang digunakan dapat menunjukkan peristiwa hukum III Newton dan mampu membuat mereka memahami peristiwa hukum III Newtons sebesar 98,61\% dan dari hasil evaluasi sebanyak 75\% siswa memperoleh nilai minimal 75. Hasil dari penelitian ini, dapat disimpulkan bahwa Alat peraga Hukum III Newton dapat dibuat dari barang bekas disekitar sebagai media pembelajaran, alat peraga BARBEKU dapat diimplementasikan dalam pembelajaran di kelas dan pemahaman siswa terhadap Hukum III Newton dapat berhasil ditingkatkan terbukti dari rata-rata hasil tes menghasilkan rata-rata $75 \%$ jumlah siswa dapat menjawab dengan benar.
\end{abstract}

Kata-kata kunci: alat peraga sederhana; barang bekas; hukum III Newton; media pembelajaran

\section{PENDAHULUAN}

Ilmu Pengetahuan Alam (IPA) pada dasarnya merupakan ilmu eksperimental yaitu ilmu yang didapatkan melalui percobaan-percoban. IPA berkembang sebagai hasil observasi terhadap gejala alam, maka mutlak diperlukan adanya usaha penanaman ketrampilan penggunaan alat indera dan alat bantu pengungkap gejala alam sejak dini. Oleh sebab itu dalam mengajarkan IPA seharusnya guru menggunakan media peraga. Trianto (2007) menyatakan bahwa untuk menunjang proses pembelajaran terpadu khususnya mata pelajaran IPA dibutuhkan suatu media pembelajaran, akan tetapi media tersebut harus memiliki kegunaan yang dapat dimanfaatkan oleh berbagai bidang studi yang terkait. Pembelajaran untuk mengenalkan hakikat IPA di sekolah harus dilakukan dengan percobaan-percobaan sehingga diperlukan suatu alat peraga yang sesuai dengan pembelajaran IPA. Penggunaan alat peraga dalam proses pembelajaran dapat membantu guru dalam memperjelas penyajian dan penyampaian informasi kepada peserta didik, sehingga peserta didik lebih mudah memahami informasi tersebut. Penggunaan alat peraga dalam pembelajaran IPA dapat membantu penyampaian konsep menjadi lebih bermakna (Sidharta dan Yamin, 2013). Pembelajaran dengan menggunakan alat peraga merupakan suatu rangkaian kegiatan untuk menyampaikan materi pelajaran yang bertujuan memberi kesempatan peserta didik untuk aktif belajar sehingga memungkinkan peserta didik memperoleh pengetahuan dan mengembangkan keterampilan psikomotorik serta menumbuhkan kreativitas peserta didik untuk memecahkan permasalahan yang dihadapi (Prasetyarini dkk., 2013).

Namun pada kenyataannya tidak semua sekolah memiliki alat peraga sebagai media pembelajaran terutama di daerah-daerah terpencil yang sulit untuk mendapatkan alat karena keterbatasan alat yang disediakan di Laboratorium, alat yang digunakan sudah rusak, ataupun ketersediaan terbatas dikarenakan 
harganya yang mahal. Dari pengalaman PPL di SMP PL Salatiga ketersediaan alat peraga hukum III Newton dalam kit mekanika yang tersedia di sekolah tidak ada. Sekolah yang tidak memiliki alat peraga (rusak atau tidak lengkap), maka diperlukan alat peraga sederhana sebagai media pembelajaran. Guru-guru wajib merekayasa benda-benda disekitar supaya alat peraga bisa digunakan dalam pembelajaran. Rochaeni (2013) menyatakan bahwa ketersediaan alat laboratorium fisika yang peneliti lakukan ke beberapa Sekolah di Jakarta Timur, didapatkan data bahwa hanya 31,25\% alat peraga Hukum Newton yang tersedia di laboratorium fisika. Pada alat peraga kit mekanika yang tersedia di sekolah, alat peraga hukum III Newton bahkan tidak ada.

Alat peraga yang selama ini digunakan untuk pembelajaran hukum III Newton hanya dengan neraca pegas. Dimana pembelajaran yang dilakukan menggunakan dua buah neraca pegas, satu di sebelah kiri dan satu di sebelah kanan yang ditarik secara bersamaan kemudian di baca. Jika konstanta pegas tidak sama maka nilai tidak sama, padahal nilai ini untuk, menunjukkan besar yang sama. Alat peraga tersebut memiliki kelemahan pada pegas, yaitu elastisitas pegas yang sudah tidak elastis lagi, dapat menurunkan kadar kelenturan pegas yang mempengaruhi akurasi hasil pengukurannya sehingga hasil yang didapat kurang tepat, maka neraca pegas sudah tidak dapat dipakai lagi. Alat peraga yang juga digunakan adalah roket air. Alat peraga tersebut memiliki kelemahan pada pipa utama yang dihubungkan selang pompa ke peluncur. Saat selang pompa dihubungkan ke peluncur maka udara masuk perlahan lahan sesuai dengan kekuatan tangan. Menyebabkan udara tersentak tiba-tiba ke pipa utama, sehingga sambungan pipa utama bocor karena lapisan lem yang kurang kuat dan merata mengakibatkan roket air tidak bisa naik ke atas dan tidak bisa menjelaskan Hukum III Newton. Penelitian pengembangan dengan menggunakan alat peraga sederhana sudah banyak dilakukan diantaranya: Alat Peraga Sederhana Berbasis Teknologi Daur Ulang untuk Meningkatkan Pemahaman Konsep Materi Vektor dalam Kelas Remedial SMKN 1 Wonoasri Tahun Pelajaran 2014/2015 menghasilkan penggunaan Alat Peraga Sederhana Berbasis Teknologi Daur Ulang dapat meningkatkan pemahaman konsep fisika siswa pada materi vektor di SMKN 1 Wonoasri tahun pelajaran 2014/2015 dengan nilai gain rata-rata 0,91 (Muzaky dan Handhika, 2015). Alat Peraga Sederhana EYE LENS tema mata kelas VIII untuk menumbuhkan ketrampilan peserta dinyatakan valid oleh pakar materi dan media sehingga layak digunakan sebagai media pembelajaran, serta alat peraga sederhana eye lens dapat menumbuhkan keterampilan proses sains peserta didik serta efektif digunakan dalam proses pembelajaran (Saputri dan Dewi, 2014). Alat Peraga Gaya Gesek yang digunakan untuk meningkatkan ketrampilan berpikir kritis siswa di SMAN 2 Pekalongan kelas $X$ menghasilkan Penggunaan alat peraga gaya gesek dapat meningkatkan keterampilan berpikir kritis, yang dinilai dari peningkatan hasil belajar peserta didik (Hartati, 2010). Pengembangan Media Pembelajaran Alat Peraga pada Materi Hukum Biot Savart di SMA Negeri 1 Prambanan Klaten menghasilkan Penggunaan alat peraga dapat bekerja dengan baik, terbukti alat dapat menentukan grafik induksi medan magnet (B) dengan sensor magnet, dari hasil penelitian dapat dibuat modul sebagai panduan praktikum fisika di sekolah, modul tersebut dapat digunakan sebagai panduan untuk melakukan praktikum pengembangan eksperimen pada materi hukum biot savart atau materi tentang magnet secara umum (Afriyanto, 2015). Alat peraga sederhana pada materi hukum III Newton dengan memanfaatkan barang bekas di sekitar ini belum ada yang mengembangkanya.

Berdasarkan permasalahan dan penelitian yang sudah dilakukan, maka dalam penelitian ini mencoba memperkaya alat peraga sederhana sebagai media pembelajaran yang sudah ada. Dengan pemikiran barang yang digunakan mudah di dapat, pasti berhasil dan harganya murah. Alat peraga sederhana ini memperkaya media pembelajaran yang mengembangkan mainan anak anak, yang selama ini hanya untuk permainan bisa digunakan sebagai media pembelajaran untuk menunjang proses pembelajaran IPA terpadu. Media pembelajaran adalah segala sesuatu yang dapat menyalurkan informasi dari guru ke siswa sehingga dapat merangsang pikiran, perasaan , perhatian serta minat siswa, sehingga informasi yang diberikan dapat lebih dipahami oleh siswa. Taraf berpikir siswa mengikuti tahap perkembangan dimulai dari berfikir kongkret menuju ke berfikir abstrak, dimulai dari berfikir sederhana menuju ke berpikir kompleks. Penggunaan media pembelajaran erat kaitannya dengan tahapan berpikir tersebut karena melalui media pembelajaran hal-hal yang abstrak dapat dikongkretkan, dan hal-hal yang kompleks bisa disederhanakan (Sudjana dan Rivai, 1990). Manfaat penggunakan media dalam proses pembelajaran antara lain yaitu: (1) memperjelas penyajian pesan dan informasi sehingga proses belajar semakin lancar dan untuk meningkatkan hasil belajar siswa, (2) meningkatkan motivasi siswa, dengan mengarahkan perhatian siswa sehingga memungkinkan siswa belajar sendiri-sendiri sesuai kemampuan dan minatnya, (3) penggunaan media dapat mengatasi keterbatasan indera, ruang, dan waktu, serta (4) siswa akan mendapat pengalaman yang sama mengenai suatu peristiwa, dan memungkinkan terjadinya interaksi langsung dengan lingkungan sekitar (Arsyad, 2007). Penggunaan alat peraga sederhana sebagai media pembelajaran dapat meningkatkan pemahaman siswa pada materi hukum 
III Newton, selain harganya murah alat peraga ini juga mempunyai unsur permainan yang disukai oleh anakanak.

Tujuan penelitian ini adalah untuk mengembangkan alat peraga sederhana pada materi Hukum III Newton dengan memanfaatkan barang-barang bekas yang ada di sekitar kita menjadi media pembelajaran, serta mengimplementasikan media pembelajaran alat peraga barbeku yang dibuat sebagai pembelajaran di kelas dan membantu siswa meningkatkan pemahaman tentang materi hukum III Newton. Manfaat penelitian media pembelajaran sederhana alternatif yang dapat digunakan dalam pembelajaran yang murah dan dapat dibuat sendiri dan memberikan ide kepada guru untuk mengembangkan media-media pembelajaran sederhana lainnya dengan barang bekas.

\section{METODE}

Penelitian ini menggunakan metode penelitian tindakan kelas (PTK) dengan tipe guru sebagai peneliti. Menurut Rochman Natawijaya, PTK adalah pengkajian terhadap permasalahan praktis yang bersifat situasional dan konteksual, yang ditunjukkan untuk menentukan tindakan yang tepat dalam rangka pemecahan masalah yang dihadapi, atau memperbaiki sesuatu (Muslich, 2012). Selain itu menurut Suyanto (2012), PTK adalah suatu bentuk penelitian yang bersifat reflektif dengan melakukan tindakan-tindakan tertentu agar dapat memperbaiki dan/atau meningkatkan praktik-praktik pembelajaran di kelas secara profesional (Muslich, 2012). PTK merupakan Penelitian Tindakan Kelas atau Classroom Action Research memiliki peranan yang sangat penting dan strategis untuk meningkatkan hasil belajar siswa apabila dilakukan dengan baik dan benar. PTK adalah suatu penelitian tindakan (Action Research) yang dilakukan oleh guru yang sekaligus sebagai peneliti di kelasnya atau bersama-sama dengan orang lain (kolaborasi). Jika PTK dilakukan secara kolaboratif, maka pengamatan dilakukan oleh kolaborator, bukan guru yang sedang melakukan tindakan. Antara tindakan (dilakukan guru) dan pengamatan (dilakukan oleh kolaborator), keduanya dilakukan secara bersamaan dalam satu waktu dan satu kelas. Tujuan utama PTK adalah untuk memecahkan permasalahan yang terjadi di kelas dan untuk meningkatkan hasil belajar siswa.

Penelitian ini dilaksanakan di SMPN 3 Tuntang Kabupaten Semarang. Penelitian berlangsung selama lima bulan dari bulan Agustus sampai bulan Desember 2018. Subjek penelitian ini adalah seluruh siswa kelas VIIIB SMPN 3 Tuntang yang berjumlah 24 siswa, terdiri dari 11 orang perempuan dan 13 orang laki-laki. Penelitian ini terbagi menjadi 3 tahapan penelitian yaitu tahap persiapan, tahap pelaksanaan dan tahap refleksi. Pada tahap persiapan, seluruh alat pengambilan data disiapkan meliputi pembuatan alat peraga sederhana dengan menggunakan barang bekas, pembuatan instrumen pengambilan data berupa (1) RPP (Rencana Pelaksanaan Pembelajaran), (2) Lembar Observasi, (3) Lembar Kuesioner, (4) soal evaluasi siswa. Pada tahap pelaksanaan, Kegiatan Belajar Mengajar (KBM) dilaksanakan berdasarkan dengan RPP yang telah dibuat dengan menggunakan alat peraga sederhana yang buat. Selama KBM berlangsung ada observer yang mengisi lembar observasi. Setelah KBM selesai siswa diberi soal evaluasi dan untuk dikerjakan. Setelah selesai mengerjakan soal evaluasi siswa diminta untuk mengisi lembar kuisioner. Tahap selanjutnya tahap refleksi, pada tahap refleksi hasil dari lembar Observasi, lembar kuisioner dan tes diolah dan dianalisis secara deskriptif kualitatif untuk mengetahui apakah Kegiatan Belajar Mengajar (KBM) mencapai target atau tidak. Penelitian dikatakan berhasil jika memenuhi kriteria dari masing-masing indikator. Jika kriteria penelitian sudah tercapai maka penelitian ini dihentikan. Tetapi jika kriteria penelitian belum tercapai maka penelitian dilanjutkan ke siklus berikutnya. Penelitian ini dilakukan berulang sampai kriteria keberhasilan tercapai dengan cara memperbaiki proses pembelajaran dari kesalahan penelitian yang sudah dilakukan.

Media yang akan dipakai sebagai media pembelajaran berupa: Kincir, Botol Plastik Bekas, Skateboard. Instrumen dalam penelitian ini adalah: (1) RPP (Rencana Pelaksanaan Pembelajaran) disusun dengan metode Discovery untuk materi hukum III Newton dengan memanfaatkan media pembelajaran alat peraga sederhana yang terbuat dari barang-barang bekas di sekitar kita, (2) Lembar Observasi berupa pertanyaan-pertanyaan sederhana untuk melihat implementasi pembelajaran yang sudah disusun dengan menggunakan alat peraga sederhana yang terbuat dari barang-barang bekas di sekitar kita dan kesesuaiannya dengan RPP serta untuk menilai keaktifan siswa saat KBM berjalan. Lembar Observasi diisi oleh observer selama KBM berlangsung, (3) Lembar Kuesioner berupa pertanyaan-pertanyaan sederhana yang digunakan untuk melihat tingkat ketertarikan siswa terhadap pembelajaran yang telah berlangsung dengan menggunakan alat peraga sederhana yang terbuat dari barang-barang bekas di sekitar kita. Lembar Kuesiner diisi pada akhir KBM, (4) soal evaluasi siswa digunakan untuk menentukan tingkat pemahaman siswa mengenai materi yang telah dipelajari, diisi pada akhir KBM. Teknik analisis data dilakukan dengan analisis deskriptif kualitatif. Lembar Observasi dan lembar kuesioner dianalisis secara deskriptif kualitatif. 
Langkah-langkah analisis meliputi: (1) Menentukan persentase ketuntasan siswa, (2) Menghitung nilai pada tes evaluasi siswa, (3) Menghitung persentase siswa yang aktif dalam lembar observasi, (4) Menghitung persentase siswa yang menjawab YA pada lembar kuisioner. Pembelajaran dikatakan berhasil apabila minimal $70 \%$ kegiatan yang terekam di lembar observasi dapat dilaksanakan sesuai dengan RPP yang di buat dan siswa memberikan respon yang positif dan aktif dalam KBM. Jika 70\% siswa memberikan respon yang positif terhadap pembelajaran yang dilakukan menggunakan alat peraga sederhana yang terbuat dari barang bekas maka media yang dibuat dan pembelajaran berhasil berdasarkan tanggapan siswa. Serta minimal 70\% dari siswa memperoleh nilai minimal 75 pada soal evaluasi dapat dikatakan siswa memahami materi yang diberikan. Apabila hasil yang didapat belum mencapai target yang diinginkan, maka perlu dilakukan perbaikan pada proses pembelajaran dan siklus diulang. Apabila hasil yang didapat sudah mencapai target yang diinginkan, maka penelitian dihentikan. Data yang diperoleh dijadikan sebagai gambaran kondisi siswa. Berdasarkan data tersebut maka dilakukan analisis terhadap proses pembelajaran yang berlangsung dalam memanfaatkan BARBEKU sebagai media pembelajaran serta implementasinya dalam peningkatan pemahaman siswa terhadap materi Hukum III Newton.

\section{HASIL DAN PEMBAHASAN}

Penelitian ini menggunakan alat peraga sederhana dari barang bekas yang mudah ditemukan di lingkungan sekitar untuk materi hukum III Newton. Alat peraga yang digunakan terdiri dari : kincir terbuat dari kertas dan bambu bekas yang di potong kecil-kecil pada ujung bambu di beri besi bekas kecil untuk letak pengait, botol plastik bekas dimanfaatkan bagian badan botol yang berbentuk lonjong, pada bagian badan botol plastik di lubangi pada tiap sisinya lalu di gantung tali di bagian atas, skateboard terbuat dari papan kayu bekas dan roda bekas mainan anak. Alat peraga sederhana ini akan didemonstrasikan guru di depan dikelas.

\section{Proses Pembelajaran}

\section{Langkah Mengamati dan Menanya Kegiatan 1}

Kegiatan belajar mengajar di awali dengan mengamati peristiwa dengan cara salah satu siswa diminta untuk maju ke depan, siswa tersebut ditugaskan untuk mendorong tembok, lalu guru menanyakan " Apa yang kamu rasakan ketika mendorong tembok ?", siswa menjawab "berat". Lalu siswa ditanya lagi "Kalau doronganmu semakin kuat, bagaimana yang kamu rasakan ?", siswa menjawab "semakin berat juga". Pada tahap Menanya guru bertanya kepada siswa: "Mengapa semakin kuat kita mendorong tembok, semakin kuat juga yang kita rasakan?". Sebanyak 20 siswa berhipotesa dengan menjawab karena ada gaya balik yang diberikan kepada kita dan 4 siswa tidak menjawab. Dari lembar observasi, sebanyak $75 \%$ siswa mencoba mengemukakan pendapatnya untuk membuat hipotesis dalam langkah menanya. Sedangkan sisanya hanya diam dan memperhatikan teman yang berbicara, mereka ragu-ragu untuk mengemukakan pendapatnya atau tidak berani untuk berbicara. Ini berarti, pada tahap mengamati dan menanya sebagian besar siswa (75\%) antusias dengan pengamatan yang dilakukan.

Setelah itu siswa diperkenalkan alat peraga yang akan digunakan pada pembelajaran ini alat peraga yang digunakan memanfaatkan bahan bekas di sekitar, alat peraga terdiri dari 3 alat yaitu kincir, botol plastik bekas dan juga skateboard. Pada kegiatan belajar mengajar akan terbagi menjadi 3 kegiatan belajar, kegiatan 1 percobaan menggunakan alat peraga kincir, kegiatan 2 percobaan menggunakan alat peraga botol plastik bekas dan kegiatan 3 percobaan menggunakan alat peraga skateboard. Rumusan masalah dalam langkah menanya dapat dimengerti oleh siswa, terlepas dari apakah jawaban mereka betul atau salah. Saat siswa memahami dengan baik langkah mengamati dan menanya maka siswa akan mengetahui yang dipelajari di langkah selanjutnya. Ini merupakan langkah yang bagus untuk masuk ke langkah mencoba. Kegiatan selanjutnya adalah melakukan percobaan untuk mengetahui kebenaran hipotesis dari siswa.

\section{Langkah Mencoba Kegiatan 1 (Kincir)}

Percobaan pertama menggunakan kincir kertas dan karet. Kegiatan 1 diawali dengan salah satu siswa untuk maju ke depan, siswa tersebut ditugaskan untuk mengambil kincir kertas, lalu meletakkan karet pada besi di bagian bawah kincir. Siswa ditugaskan untuk menaarik kincir ke bawah dengan pelan, tahan sebentar lalu lepaskan dan siswa diminta mengamati apa yang terjadi. Percobaan diulangi dengan menarik kincir dengan kuat. Alat peraga sederhana Kincir dan penggunaanya dapat dilihat pada Gambar 1. 


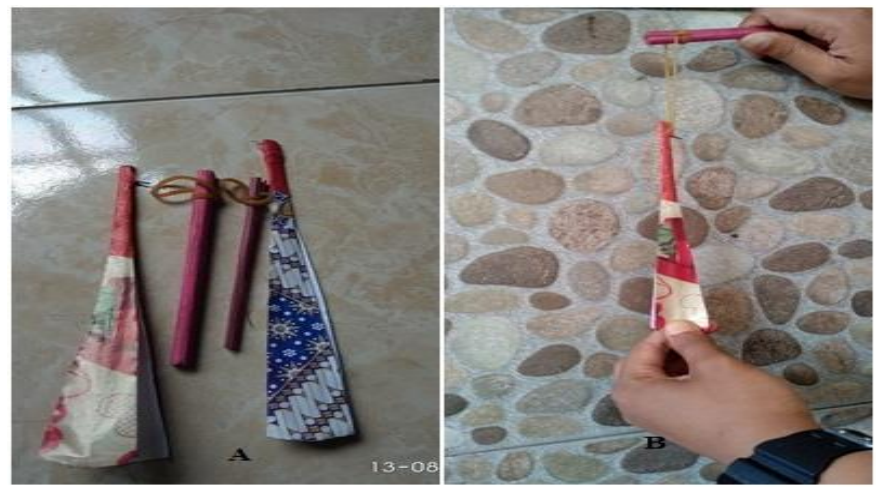

Gambar 1. Alat peraga Kincir danPenggunaanya

Siswa diminta untuk mengamati percobaan dan diminta menjawab pertanyaan guru, "Kemana arah kincir menarik karet?", 24 siswa menjawab dengan benar. Dilanjutkan dengan pertanyaan "Setelah dilepas kemana arah kincir?" sebanyak 18 siswa menjawab dengan benar "naik ke atas", siswa ditanya lagi "Apakah arah naik sama dengan arah tarikan karet?" sebanyak 20 siswa menjawab dengan benar. "berlawanan arah", "Ketika kincir ditarik biasa/pelan, bagaimana kecepatan naiknya kincir?" 18 siswa menjawab pertanyaan dengan benar "kincir naik dengan kecepatan pelan", " Ketika kincir ditarik kuat, bagaimana kecepatan naiknya kincir?" 20 siswa menjawab pertanyaan dengan benar "kincir naik dengan kecepatan kuat". Pada saat menulis hasil pegamatan salah satu siswa diminta untuk maju kedepan dan menuliskan hasil pengamatan dari percobaan yang sudah diamati. Hasil pengamatan di tulis di papan tulis hasil dari percobaan kincir yaitu , Kincir menarik karet ke bawah, setelah dilepas kincir bergerak naik ke atas, Arah naiknya kincir berlawanan arah tarikan karet, Ketika kincir ditarik biasa/pelan, kincir naik dengan kecepatan pelan, Ketika kincir ditarik kuat, kincir naik dengan kecepatan pelan kuat/cepat.

Pada saat percobaan berlangsung siswa sangat antusias melihat percobaan dan merasa tertarik dengan percobaan yang dilakukan. Hal ini terlihat dengan banyaknya siswa yang maju ke depan kelas dan mengajukan beberapa pertanyaan tentang percobaan yang dilakukan. Siswa mulanya diam saja, tidak berani mengemukakan pendapatnya pada langkah mengamati dan menanya kini mereka mulai berani berbicara dan aktif dalam pembelajaran. Terlihat dari banyaknya siswa yang ingin mencoba sendiri menggunakan alat peraga sederhana. Penggunaan alat peraga ini mengundang keingintahuan siswa terhadap peristiwa hukum III Newton. Rasa ingin tahu ini muncul karena siswa menggangap bahwa pembelajaran dengan alat peraga sederhana dari barang bekas merupakan pembelajaran baru bagi mereka. Menurut siswa, pembelajaran dengan alat peraga sederhana dari barang bekas sebagai media pembelajaran adalah hal yang sangat menyenangkan.

Dengan bantuan pertanyaan penggiring, siswa dapat menyimpulkan cara kerja kincir berdasarkan hukum III Newton. Dari lembar observasi, sebanyak 77\% siswa dapat menjawab cara kerja kincir dengan benar. Sebanyak $75 \%$ siswa dapat menyimpulkan cara kerja kincir berdasarkan hukum III Newton. Dari lembar kuesioner, sebanyak 100\% siswa menjawab bahwa peristiwa hukum III Newton (aksi-reaksi) pada alat peraga dapat diamati dengan jelas karena Kincir menarik karet ke bawah setelah dilepas kincir bergerak naik ke atas, arah naiknya kincir berlawanan arah tarikan karet. Ketika kincir ditarik pelan, kincir naik dengan kecepatan pelan, ketika kincir ditarik kuat, kincir naik dengan kecepatan kuat/cepat. Sebanyak 100\% siswa menjawab bahwa alat peraga yang digunakan mampu membuat mereka memahami peristiwa hukum III Newton (aksi-reaksi). Berdasarkan data ini, sebuah kincir yang menarik karet ke bawah lalu dilepaskan maka kincir bergerak naik ke atas dapat berfungsi untuk menunjukan peristiwa hukum Newton III(aksi-reaksi). Meskipun alat yang digunakan sederhana, hanya dengan kincir dan karet tapi dapat menunjukan antara gaya aksi dan reaksi gejala hukum III Newton tampak sangat jelas.

\section{Langkah Mencoba Kegiatan 2 (Botol Plastik)}

Percobaan kedua menggunakan dua buah botol plastik bekas A dan B yang dilubangi tiap sisinya dan digantungkan dengan sebuah tali pada sisi atas botol. Alat peraga didemonstrasikan di depan kelas oleh guru. Botol plastik bekas A dipegang oleh guru di bagian ujung tali, siswa diminta untuk mengamati apa yang terjadi pada botol plastik A dan diberi pertanyaan "Ketika botol plastik masih kosong apakah botol plastik berputar ?", sebanyak 21 siswa menjawab dengan benar yaitu "botol plastik diam/tidak berputar". Kemudian guru melanjutkan percobaan lagi, guru memegang botol plastik dan diisi air kemudian guru bertanya kepada siswa "Ketika botol plastik diisi air apakah botol plastik berputar?", "Apakah arah keluar air sama dengan arah putaran botol plastik ?" sebagian besar siswa menjawab dengan benar pertanyaan yang diberikan. Hasil 
pengamatan menunjukkan bahwa botol plastik yang kosong tidak berputar, sedangkan botol plastik yang di isi air akan berputar. Salah satu siswa ditugaskan untuk menuliskan hasil pengamatan di papan tulis, dan siswa lainnya diminta untuk menuliskan pada buku mereka masing-masing. Alat peraga sederhana botol plastik dan penggunaanya dapat dilihat Gambar 2.

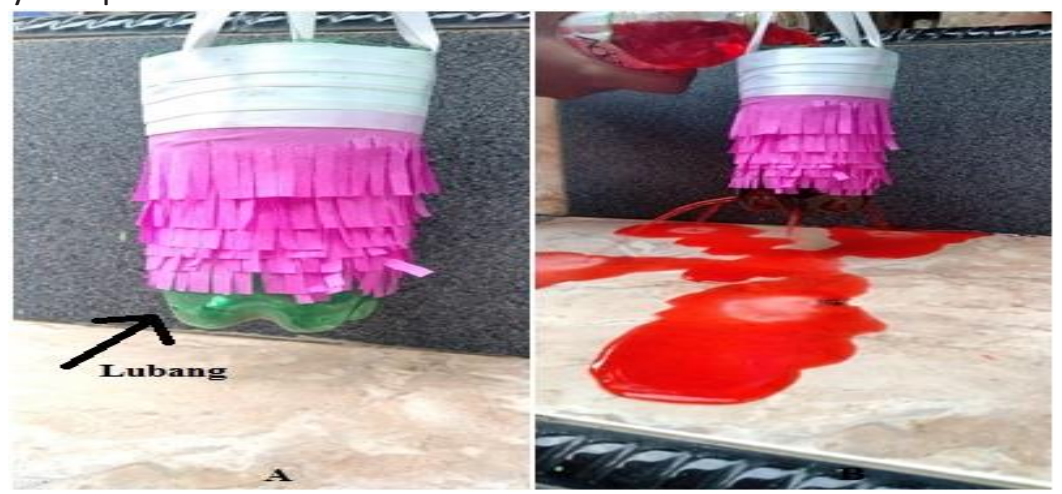

Gambar 2. Alat Peraga Sederhana Botol Plastik Bekas dan Penggunaannya

Selanjutnya siswa digiring untuk menyimpulkan apakah semua syarat hukum III Newton terpenuhi dalam peristiwa berputarnya botol plastik ketika diisi air melalui pertanyaan yang diberikan guru. Dengan bantuan pertanyaan penggiring, siswa dapat menyimpulkan pada peristiwa berputarnya botol plastik ketika di isi air, semua syarat hukum III Newton (aksi-reaksi) terpenuhi yaitu syarat aksi-reaksi yang pertama bekerja pada 2 buah benda yang berbeda, yaitu air dalam botol plastik mendorong udara dan udara mendorong air dalam botol plastik sehingga berputar. Syarat aksi-reaksi yang kedua besarnya sama, dibuktikan dengan putaran dari botol plastik sama/stabil jika besarnya putaran dari botol plastik tidak sama maka putaran dari botol plastik oleng. Syarat aksi-reaksi yang ketiga arahnya berlawanan, gaya aksi air dalam botol plastik mendorong udara ke kiri sehingga air menyembur keluar dari masing-masing lubang. Reaksinya udara mendorong air dalam botol plastik sehingga berputar ke kanan. Dari lembar observasi, sebanyak $98 \%$ siswa dapat menjawab pertanyaan dengan benar. Sebanyak $71 \%$ siswa dapat menyimpulkan pada peristiwa berputarnya botol plastik ketika di isi air, semua syarat hukum III Newton (aksi-reaksi) terpenuhi dengan benar dan tepat.

Dari lembar kuesioner, sebanyak 100\% siswa menjawab alat peraga sederhana dari barang bekas yang digunakan dapat menunjukkan peristiwa hukum III Newton. Sebanyak $98,61 \%$ siswa menjawab bahwa peristiwa hukum III Newton (aksi-reaksi) pada alat peraga sederhana dari barang bekas dapat diamati dengan jelas, dan $1.39 \%$ siswa menjawab tidak dapat diamati dengan jelas dengan alasan arah keluarnya air kurang jelas diamati. Sebanyak $98.61 \%$ siswa menjawab bahwa alat peraga sederhana dari barang bekas yang digunakan mampu membuat siswa memahami peristiwa hukum III Newton (aksi-reaksi). Hal ini berarti, botol plastik bekas dapat digunakan untuk menunjukkan peristiwa hukum III Newton (aksi-reaksi). Pada saat percobaan kedua dilakukan, siswa menunjukan minat yang positif. Siswa terlihat semakin aktif dan bersemangat mengikuti kegiatan belajar mengajar karena siswa merasa mudah memahami dan siswa lebih banyak terlibat langsung dalam pembelajaran sehingga siswa tidak mengantuk pada kegiatan belajar mengajar berlangsung. Siswa merasa senang mempelajari hukum III Newton (aksi-reaksi) dengan penggunaan alat peraga sederhana dalam pembelajaran.

\section{Langkah Mencoba Kegiatan 3 (Skateboard)}

Percobaan ketiga menggunakan skateboard. Alat peraga didemonstrasikan didepan kelas oleh salah satu siswa yang diminta maju ke depan untuk menaiki skateboard dan mendorong tembok dengan menggunakan satu tangan. Siswa lainnya diminta untuk mengamati apa yang terjadi dengan skateboard. Hasil pengamatan menunjukkan bahwa saat siswa mendorong tembok dengan pelan, maka skateboard terdorong ke belakang dengan pelan. Sedangkan saat siswa mendorong tembok dengan kuat, maka skateboard terdorong ke belakang dengan kuat. Siswa diminta untuk menulis hasil pengamatan yang di peroleh dari percobaan yang telah dilakukan. Salah satu siswa ditugaskan untuk maju ke depan dan menulis hasil pengamatan di papan tulis, dan siswa lainnya diminta untuk menulis hasil pengamatan pada buku mereka masing-masing. Alat peraga sederhana botol plastik dan penggunaanya dapat dilihat Gambar 3. 


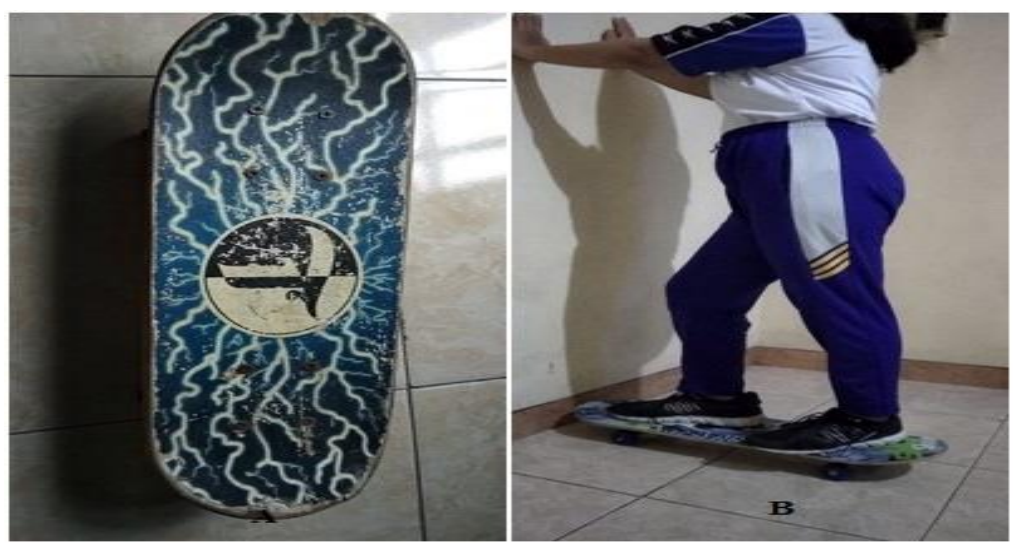

Gambar 3. Skateboard dan Cara Kerjanya

Selanjutnya guru menggiring siswa untuk menyimpulkan apakah syarat hukum Newton III (aksireaksi) terpenuhi dalam peristiwa ini. Dengan bantuan pertanyaan penggiring, siswa dapat menyimpulkan pada peristiwa siswa mendorong tembok, semua syarat hukum Newton III (aksi-reaksi) terpenuhi yaitu syarat aksi-reaksi yang pertama bekerja pada 2 buah benda yang berbeda, yaitu tangan mendorong tembok ke depan, tembok mendorong tangan ke belakang sehingga skateboard meluncur ke belakang. Syarat aksireaksi yang kedua besarnya sama, dibuktikan dengan saat kamu mendorong tembok dengan pelan, maka skateboard terdorong ke belakang dengan pelan. Saat kamu mendorong tembok dengan kuat, maka skateboard terdorong ke belakang dengan cepat/kuat. Syarat aksi-reaksi yang ketiga arahnya berlawanan yaitu $\mathrm{Fa}=$ tangan mendorong tembok ke depan, $\mathrm{Fr}=$ tembok mendorong tangan ke belakang sehingga skateboard meluncur ke belakang.

Dari lembar observasi, sebanyak $96 \%$ siswa dapat menjawab pertanyaan dengan benar. Sebanyak 96\% siswa dapat menyimpulkan pada peristiwa siswa mendorong tembok, semua syarat hukum III Newton (aksi-reaksi) terpenuhi. Dari lembar kuisioner, sebanyak 100\% siswa menjawab bahwa alat peraga sederhana dari barang bekas yang digunakan betul-betul dapat menunjukkan peristiwa hukum III Newton (aksi-reaksi). Sebanyak $100 \%$ siswa menjawab bahwa hukum III Newton (aksi-reaksi) dapat diamati dengan jelas. Sebanyak 98.61\% siswa menyatakan bahwa alat peraga sederhana dari barang bekas yang digunakan mampu membuat mereka memahami peristiwa hukum III Newton (aksi-reaksi). Berdasarkan data yang diperoleh, skateboard yang digunakan pada saat kegiatan belajar mengajar berfungsi untuk menunjukkan persitiwa hukum III Newton (aksi-reaksi) dengan jelas sehingga alat peraga tersebut dapat digunakan sebagai alat peraga sederhana dalam proses pembelajaran pada materi hukum III Newton (aksi-reaksi). Pada saat tahap mencoba 3 , siswa semakin aktif berinteraksi dengan guru atau dengan siswa lainnya. Banyak siswa yang ingin maju ke depan untuk mecoba skateboard sendiri agar dapat merasakan sendiri dan mencari tahu sendiri hasil percobaan agar lebih jelas.

\section{Respon Siswa Dalam Pembelajaran}

Lembar observasi diisi oleh observer selama RPP diimplementasikan di dalam kelas. Respon siswa selama Kegiatan Belajar Mengajar (KBM) yang berlangsung terlihat dari data lembar observasi. Hasil observasi dapat dilihat pada Tabel 1.

Tabel 1. Rekapitulasi Lembar Observasi

\begin{tabular}{cllccc}
\hline \multirow{2}{*}{ No } & \multirow{2}{*}{ Fase } & \multicolumn{1}{c}{ Indikator } & \multicolumn{3}{c}{ Observer } \\
\cline { 3 - 5 } & & A & B & Rata-Rata \\
\hline 1 & Menanya & 1. Berapa siswa yang mencoba berhipotesis? & $75 \%$ & $75 \%$ & $75 \%$ \\
\hline 2 & $\begin{array}{l}\text { Mencoba } \\
\text { dan Menalar }\end{array}$ & $\begin{array}{l}\text { Percobaan 1 (Kincir) } \\
\text { 1. Berapa siswa yang menjawab hasil percobaan dengan } \\
\text { benar? }\end{array}$ & $54 \%$ & $100 \%$ & $77 \%$ \\
& $\begin{array}{l}\text { 2. Berapa siswa yang dapat menyimpulkan pengertian Hukum } \\
\text { Newton 3 dengan benar? }\end{array}$ & $96 \%$ & $54 \%$ & $75 \%$ \\
& $\begin{array}{l}\text { Percobaan 2 (Botol Plastik bekas) } \\
\text { 1. Berapa siswa yang menjawab hasil percobaan dengan } \\
\text { benar }\end{array}$ & $100 \%$ & $96 \%$ & $98 \%$ \\
& $\begin{array}{l}\text { 2. Berapa siswa yang dapat menyimpulkan pengertian Hukum } \\
\text { Newton 3 dengan benar? }\end{array}$ & $83 \%$ & $58 \%$ & $71 \%$ \\
\hline
\end{tabular}




\begin{tabular}{|c|c|c|c|c|c|}
\hline \multirow{5}{*}{ No } & \multirow{5}{*}{ Fase } & \multirow{2}{*}{ Indikator } & \multicolumn{3}{|c|}{ Observer } \\
\hline & & & A & B & Rata-Rata \\
\hline & & \multicolumn{4}{|l|}{ Percobaan 3 (skateboard) } \\
\hline & & $\begin{array}{l}\text { 1. Berapa siswa yang menjawab hasil percobaan dengan } \\
\text { benar? }\end{array}$ & $54 \%$ & $96 \%$ & $75 \%$ \\
\hline & & $\begin{array}{l}\text { 2. Berapa siswa yang dapat menyimpulkan pengertian Hukum } \\
\text { Newton } 3 \text { dengan benar? }\end{array}$ & $96 \%$ & $54 \%$ & $75 \%$ \\
\hline \multirow[t]{5}{*}{3} & $\begin{array}{l}\text { Mengomuni- } \\
\text { kasikan }\end{array}$ & $\begin{array}{l}\text { 1. Berapa siswa yang dapat menjawab pengertian Hukum } \\
\text { Newton } 3 \text { dengan benar dan tepat? }\end{array}$ & $96 \%$ & $96 \%$ & $96 \%$ \\
\hline & & $\begin{array}{l}\text { 2. Berapa siswa yang dapat mejawab syarat -syarat dari } \\
\text { hukum Newton } 3 \text { dengan benar dan tepat? }\end{array}$ & $96 \%$ & $54 \%$ & $76 \%$ \\
\hline & & $\begin{array}{l}\text { 3. Berapa siswa yang menjawab contoh-contoh hukum } \\
\text { Newton } 3 \text { dalam kehidupan sehari-hari dengan benar dan } \\
\text { tepat? }\end{array}$ & $96 \%$ & $54 \%$ & $76 \%$ \\
\hline & & Nilai Rata-rata Observer & $85 \%$ & $74 \%$ & $79.17 \%$ \\
\hline & & Nilai Observasi & & 79.1 & \\
\hline
\end{tabular}

Berdasarkan data lembar observasi, didapatkan rata-rata 79,17\% siswa memberikan reaksi yang positif selama proses pembelajaran berlangsung. Respon tersebut dalam bentuk keaktifan dan antusias siswa dalam menjawab pertanyaan-pertanyaan penggiring yang diberikan guru, berhipotesa, mencoba menganalisis dengan ketiga alat peraga yang digunakan. Secara garis besar pembelajaran fisika dengan alat peraga sederhana dari barang bekas membuat siswa tertarik dan dapat diikuti oleh siswa. Pembelajaran dengan menggunakan alat peraga ini memberikan pengalaman secara langsung pada siswa tentang peristiwa Hukum III Newton. Sehingga siswa mendapatkan kebenaran konsep melalui pengalaman langsung yang nyata sesuai alat peraga yang dilihatnya dalam percobaan. Pengalaman tersebut memberikan wawasan dan pemahaman yang lebih bagi siswa yang sulit ditunjukkan melalui pembelajaran ceramah. Beberapa siswa yang belum mampu menjawab pertanyan dengan benar pada masing-masing alat peraga yang digunakan disebabkan karena siswa tidak mengamati percobaan, serta siswa asik sendiri berbicara kepada teman sebelahnya dan tidak memperhatikan guru saat menjelaskan. Namun sebagian besar siswa sangat tertarik dan merasa senang dengan alat peraga sederhana yang digunakan karena sering kali proses pembelajaran hanya dilakukan dengan metode ceramah dan siswa kurang terlibat dalam pembelajaran sehingga mengakibatkan siswa mengantuk pada waktu Kegiatan Belajar Mengajar (KBM) berjalan. Berdasarkan data yang diperoleh diatas, terlihat bahwa siswa mampu mengikuti langkah-langkah proses pembelajaran menggunakan alat peraga sederhana dengan baik dan melalui alat peraga yang digunakan siswa lebih memahami materi hukum III Newton.

\section{Pemahaman Siswa}

Setelah kegiatan belajar mengajar selesai, siswa diberikan soal evaluasi sebanyak sembilan soal. Setelah siswa selesai mengerjakan soal evaluasi, lembar soal evaluasi beserta jawabannya dikumpulkan. Kemudian lembar jawaban siswa dikoreksi dan nilai siswa direkap seperti pada Tabel 2 .

Tabel 2. Nilai Tes Siswa

\begin{tabular}{clc}
\hline No & \multicolumn{1}{c}{ Kriteria } & Hasil \\
\hline 1 & Rata-rata skor & 75,04 \\
2 & Standar Deviasi & 14,18 \\
3 & Skor maksimal & 100 \\
4 & Skor minimal & 0 \\
5 & Jumlah yang tuntas & 18 \\
6 & Jumlah yang tidak tuntas & 6 \\
7 & Persentase ketuntasan siswa & $75 \%$ \\
\hline
\end{tabular}

Berdasarkan presentase keberhasilan yang diperoleh, pembelajaran yang dilakukan berhasil membuat siswa paham pengertian Hukum III Newton dan mampu menerapkan Hukum III Newton pada soal. Pembelajaran yang menggunakan alat peraga sederhana sebagai media pembelajaran akan dipahami siswa dengan lebih baik, serta menarik minat atau respon yang baik. Respon yang diberikan oleh siswa akan berpengaruh pada hasil belajar yang akan diperoleh. Respon siswa yang baik akan mempengaruhi segi 
pemahaman, pengetahuan, dan hasil belajar siswa yang baik pula. Sebanyak 6 orang siswa yang mendapat nilai di bawah kriteria keberhasilan disebabkan karena siswa pada saat mengerjakan tes evaluasi sambil berbicara sehingga siswa kehabisan waktu untuk mengerjakan karena bel istirahat berbunyi, serta ada siswa yang tidak memperhatikan dan tidak mengamati percobaan pada saat percobaan dilakukan. Namun, secara garis besar, penggunaan alat peraga dari barang bekas sebagai media pembelajaran pada materi hukum III Newton di dalam kelas merupakan hal yang baru dan sangat menarik dan menyenangkan bagi siswa karena ada unsur permainannya dalam alat peraga ini, serta dapat mempermudah siswa dalam memahami peristiwa hukum III Newton.

\section{Tanggapan Siswa}

Tanggapan siswa terhadap pembelajaran dengan menggunakan alat peraga sederhana dari barang bekas di lingkungan sekitar (kincir, botol plastik bekas, dan skateboard) sebagai media pembelajaran dalam materi hukum III Newton untuk meningkatkan pemahaman siswa pada materi hukum III Newton diperoleh melalui lembar kuisioner. Hasil rekapitulasi dari lembaran kuesioner dapat dilihat pada Tabel 3. Sebanyak $100 \%$ siswa menjawab bahwa model pembelajaran dengan menggunakkan kincir merupakan hal yang baru bagi mereka dengan alasan belum pernah menjumpai pembelajaran dengan cara seperti ini sebelumnya, pembelajaran yang biasanya hanya teori saja tidak pernah ada praktikumnya. Sebanyak $97,22 \%$ siswa berpendapat bahwa model pembelajaran dengan botol plastik bekas sebagai media pembelajaran adalah hal yang menarik bagi mereka dengan alasan siswa dapat praktek langsung dan pada percobaaan tersebut dapat menunjukkan peristiwa hukum III Newton dengan baik. Siswa yang lainnya yaitu $2,78 \%$ jumlah siswa berpendapat model pembelajaran dengan botol plastik bekas sebagai media pembelajaran bukanlah hal yang menarik dengan alasan pada percobaan tersebut belum jelas menunjukkan peristiwa hukum III Newton. Sebanyak 98,61\% siswa berpendapat bahwa model pembelajaran dengan menggunakan skateboard sebagai media pembelajaran adalah hal yang menarik bagi siswa dengan alasan siswa dapat terlibat langsung dalam percobaan sehingga dapat menambah pengetahuan, dan pembelajaran seperti ini menyenangkan karena seperti bermain game.

Menurut siswa pembelajaran dengan menggunakan alat peraga sederhana sebagai media pembelajaran adalah hal yang menarik karena siswa dapat terlibat langsung dalam percobaan, dan pembelajaran seperti ini menyenangkan karena seperti bermain game. Jadi dapat disimpulkan bahwa (1) pembelajaran dengan menggunakkan alat peraga sederhana dapat dijadikan sebagai media pembelajaran pada materi hukum Newton III, dan (2) secara keseluruhan penggunaan alat peraga sederhana sebagai media pembelajaran untuk materi hukum III Newton merupakan hal yang menarik dan menyenangkan serta dapat mempermudah memahami materi hukum III Newton untuk siswa.

Berdasarkan hal tersebut, 3 alat peraga sederhana dari barang bekas yang digunakan dapat menunjukkan hukum III Newton dan dapat berfungsi dengan baik. Hal ini terlihat dari ke tiga alat peraga dapat menunjukan persitiwa hukum III Newton dengan sangat jelas. Semua syarat hukum III Newton (aksi-reaksi) terpenuhi yaitu bekerja pada 2 buah benda yang berbeda, besarnya sama,arahnya berlawanan. Sehingga siswa dapat melihat secara langsung alat tersebut bekerja sehingga bisa terlihat syarat hukum III Newton (aksi-reaksi) terpenuhi . Selain itu, siswa pun lebih memahami peristiwa hukum III Newton.

Tabel 3 . Lembar Kuesioner

\begin{tabular}{|c|c|c|c|c|}
\hline No & Fase & Pertanyaan & Skor & Rata-rata \\
\hline \multirow{3}{*}{1} & \multirow{3}{*}{$\begin{array}{l}\text { Percobaan } 1 \\
\text { (Kincir) }\end{array}$} & 1. Apakah alat peraga yang digunakan bisa menunjukan peristiwa Hukum & $100 \%$ & \multirow{3}{*}{$100 \%$} \\
\hline & & $\begin{array}{l}\text { 2. Apakah peristiwa Hukum Newton } 3 \text { pada alat peraga dapat kalian amati } \\
\text { dengan jelas? }\end{array}$ & $100 \%$ & \\
\hline & & $\begin{array}{l}\text { 3. Apakah alat peraga yang digunakan mampu membuat kalian memahami } \\
\text { peristiwa Hukum Newton } 3 \text { ? }\end{array}$ & $100 \%$ & \\
\hline \multirow{3}{*}{2} & \multirow{3}{*}{$\begin{array}{c}\text { Percobaan } 2 \\
\text { (Botol } \\
\text { Plastik) }\end{array}$} & $\begin{array}{l}\text { 1. Apakah alat peraga yang digunakan bisa menunjukan peristiwa Hukum } \\
\text { Newton } 3 \text { ? }\end{array}$ & $100 \%$ & \multirow{3}{*}{$99 \%$} \\
\hline & & $\begin{array}{l}\text { 2. Apakah peristiwa Hukum Newton } 3 \text { pada alat peraga dapat kalian amati } \\
\text { dengan jelas? }\end{array}$ & $98,60 \%$ & \\
\hline & & $\begin{array}{l}\text { 3. Apakah alat peraga yang digunakan mampu membuat kalian memahami } \\
\text { peristiwa Hukum Newton } 3 \text { ? }\end{array}$ & $98,60 \%$ & \\
\hline \multirow{3}{*}{3} & \multirow{3}{*}{$\begin{array}{l}\text { Percobaan } 3 \\
\text { (Skateboard) }\end{array}$} & $\begin{array}{l}\text { 1. Apakah alat peraga yang digunakan bisa menunjukan peristiwa Hukum } \\
\text { Newton } 3 \text { ? }\end{array}$ & $100 \%$ & \multirow{3}{*}{$99,53 \%$} \\
\hline & & $\begin{array}{l}\text { 2. Apakah peristiwa Hukum Newton } 3 \text { pada alat peraga dapat kalian amati } \\
\text { dengan jelas? }\end{array}$ & $100 \%$ & \\
\hline & & $\begin{array}{l}\text { 3. Apakah alat peraga yang digunakan mampu membuat kalian memahami } \\
\text { peristiwa Hukum Newton } 3 \text { ? }\end{array}$ & $98,60 \%$ & \\
\hline
\end{tabular}




\section{KESIMPULAN}

Hasil penelitian menunjukkan bahwa pembelajaran dengan menggunakan alat peraga sederhana dari barang bekas, data lembar observasi menunjukkan 79,17\% siswa dapat mengikuti kegiatan belajar mengajar dengan baik terlihat dari siswa aktif dalam menjawab setiap pertanyaan-pertanyaan yang dilontarkan oleh guru. Hal ini didukung dengan hasil kuesioner, sebanyak $98,61 \%$ siswa menyatakan bahwa alat peraga sederhana yang digunakan dapat menunjukkan peristiwa hukum III Newton, alat peraga yang digunakan mampu membuat mereka memahami peristiwa hukum III Newton, dan alat peraga yang digunakan ada/mudah ditemukan di lingkungan sekitar. Dari hasil tes evaluasi, sebanyak $75 \%$ siswa memperoleh nilai minimal 75.

Berdasarkan hasil dan pembahasan yang telah dibuat dapat disimpulkan bahwa (1) alat peraga Hukum III Newton dapat dibuat dari barang bekas disekitar sebagai media pembelajaran; (2) alat peraga BARBEKU dapat diimplementasikan dalam pembelajaran di kelas terbukti dari 79,17\% jumlah siswa dapat mengikuti langkah-langkah pembelajaran menggunakan alat peraga sederhana dengan baik; serta (3) pemahaman siswa terhadap Hukum III Newton dapat berhasil ditingkatkan terbukti dari rata-rata hasil tes menghasilkan rata-rata $75 \%$ jumlah siswa dapat menjawab dengan benar tes evaluasi yang diberikan.

Hasil observasi, kuesioner, dan evaluasi telah memenuhi kriteria keberhasilan, sehingga penggunaan alat peraga sederhana dengan menggunakan barang bekas di sekitar pada materi Hukum III Newton dapat dimanfaatkan sebagai alternatif media pembelajaran IPA pada materi Hukum III Newton.

\section{DAFTAR PUSTAKA}

Arsyad, A. 2007. Media Pembelajaran. Jakarta: Raja Grafindo Persada.

Afriyanto, E. 2015. Pengembangan Media Pembelajaran Alat Peraga pada Materi Hukum Biot Savart di SMA Negeri 1 Prambanan Klaten. Jurnal Riset Dan Kajian Pendidikan Fisika (JRKPF UAD ). Vol.2 No.1. Retrieved http://iournal.uad.ac.id/index.php/JRKPF//article/view/3131. 06032019

Hartati, B. 2010. Pengembangan Alat Peraga Gaya Gesek Untuk Meningkatkan Keterampilan Berpikir Kritis Siswa SMA. Jurnal Pendidikan Fisika Indonesia, 06(2010):128-132. Retrieved http://journal.unnes.ac.id//nju//index.php/JPFI//article/view/1125. 25062018.

Muslich, M. 2012. Melaksanakan PTK itu Mudah. Jakarta. Bumi Aksara.

Muzaky, A. F., dan Handhika, J. 2015. Penggunaan Alat Peraga Sederhana Berbasis Teknologi Daur Ulang untuk Meningkatkan Pemahaman Konsep Materi Vektor dalam Kelas Remedial SMKN 1 Wonoasri Tahun Pelajaran 2014/2015. Yogyakarta: Makalah dipresentasikan pada Seminar Nasional Fisika dan Pendidikan Fisika (SNFPF) Ke-6.

Prasetyarini, A., Fatmaryanti, S.D. dan Akhdinirwanto, R.W. 2013. Pemanfaatan Alat Peraga Sederhana IPA Untuk Peningkatan Pemahaman Konsep Fisika Pada Siswa SMP Negeri 1 Buluspesantren Kebumen Tahun Pelajaran 2012/ 2013. Radiasi. 2 (1): 7-10. Retrieved http://download.portalgaruda.org. 23082018.

Rochaeni, S. 2015. Pengembangan Alat Peraga Fisika SMA Materi Hukum Newton Dan Aplikasinya. Jakarta : Makalah dipresentasikan Seminar Nasional Fisika 2015 di Universitas Negeri Jakarta.

Saputri, V. A. C., dan Dewi, N. R. 2014. Pengembangan Alat Peraga Sederhana Eye Lens Tema Mata Kelas VIII Untuk Menumbuhkan Ketrampilan Peserta Didik . Jurnal Pendidikan IPA Indonesia (JPII), 3 (2), 109115. Retrieved http://journal.unnes.ac.id/nju/index.php/ipii//article/view/3108. 12062018.

Sidharta, A., dan Widuono, Y. 2013. Pengembangan Alat Peraga Sederhana Praktik (APP) IPA Sederhana Untuk Guru SMP.Bandung: P4TK IPA.

Sudjana, N., dan Rivai, A. 1990. Media Pengajaran (penggunaan dan pembuatannya). Bandung: C.V.Sinar Baru Bandung.

Suyanto. 2012. Pedoman Penelitian Tindakan Kelas. Yogyakarta : Dirjen dikti BP3 GQSD.

Trianto. 2007. Model Pembelajaran Terpadu dalam Teori dan Praktek. Jakarta: Prestasi Pustaka Publisher. 